\title{
Impact of Leverage and Debt Maturity on Investment Decisions of Vietnam's Enterprises
}

\author{
TRÀN THỊ THÙY LINH \\ University of Economics HCMC - linhtcdn@ueh.edu.vn
}

TẠ TH!̣ THÚY

thuy.tathi1312@gmail.com

\begin{tabular}{ll} 
ARTICLE INFO & ABSTRACT \\
\hline $\begin{array}{l}\text { Article history: } \\
\text { Received: } \\
\text { Dec. 2, 2013 }\end{array}$ & $\begin{array}{l}\text { The research aims to analyze the impact of financing decisions on } \\
\text { investment ones and examine the relationships between leverage, debt } \\
\text { maturity structure, investment and growth opportunities. A system- } \\
\text { based model is employed, including three structural equations in } \\
\text { which leverage, debt maturity and investment are adopted as } \\
\text { Feb. 12, 2014 } \\
\text { Accepted: } \\
\text { March 31, 2014 } \\
\text { listed on HOSE and HNX in the period 2007-2012. The results } \\
\text { indicate that financial leverage negatively correlates with investment } \\
\text { decisions, whereas no correlation is revealed between debt maturity } \\
\text { and corporate investment, which is compliant with findings by Dang } \\
\text { (2011) and Aivazian et al. (2005). Accordingly, for Vietnamese } \\
\text { enterprises, there exists an interaction among leverage, debt maturity } \\
\text { and investment. Financial leverage and debt maturity are used as } \\
\text { alternative strategies to control corporate liquidity. }\end{array}$ \\
\hline $\begin{array}{l}\text { Keywords: } \\
\text { financial leverage, debt } \\
\text { maturity, investment }\end{array}$ &
\end{tabular}




\section{INTRODUTION}

Capital structure has emerged as one of the highly controversial issues in corporate finance. Based on the study by Modigliani \& Miller (1958), a question is raised: how does a mixture of debt and equity in its capital structure affect a corporate value? The paper, by checking the interactions between financing and investment decisions by Vietnamese companies in an approach suggested by Aivazian et al. (2005a, 2005b) and Dang (2011), tries to examine the relationship and impact of corporate financing decisions on investment ones, thereby addressing the research questions:

(1) Are there interactions between leverage and debt maturity in investment decisions by Vietnamese companies?

(2) How are leverage and debt maturity employed by Vietnamese companies to reduce underinvestment?

Panel data and a system-based model, along with OLS and GMM methods, are employed in the research to test the models.

\section{THEORETICAL FRAMEWORK AND EMPIRICAL RESEARCHES}

\section{a. Theories:}

According to the theory of agency costs by Jensen \& Meckling (1976), an interaction between managers, shareholders, and creditors will create barriers due to the appearance of agency problems, leading to overinvestment and underinvestment. Instead of maximizing shareholder's assets, managers may focus on investment in productive projects to increase the corporate size and reputation, thereby receiving higher salary as the fruits of the expansion (Berk \& DeMarzo, 2007). Modigliani \& Miller (1958) argue that corporate investment policy should rely on determinants that increase profits, cash flow and net worth.

Concerning the pecking order theory popularized by Myers \& Majluf (1984), firms need to use retained profit (internal financing) as a primary source. If this cannot meet investment demands, firms will seek external financing by issuing shares. Should external source, as Myers \& Majluf (1984) also suggest, be what is in need, firms would select debt as the safest form, and then such hybrid securities as convertible bonds and shares issuance is usually considered as the last resort.

\section{b. Relationships between Leverage, Debt Maturity and Investment:}

- Relationship between Leverage and Investment: 
High leverage beyond control reduces the coalition of managers and shareholders in the control overinvestment in projects with positive NPV. Since accumulated benefits for owners are higher than those for creditors, firms with high leverage are less likely to grasp growth opportunities than those with low leverage, as suggested by the theory of investment under the impact of liquidity. Firms with large debts would reduce their investment in spite of good growth opportunities (Myers, 1977).

- Relationship between Debt Maturity and Investment:

According to Myers (1977), debt maturity exerts certain effects on corporate investment. He concludes that, "If debt matures after the expiration of the firm's investment option, it reduces the incentives of the shareholder-management coalition in control of the firm to invest in positive NPV projects because benefits accrue, at least partially, to the bondholders. Hence, compared to firms with shorter debt maturities, those with long-term debt are less likely to exploit valuable growth opportunities."

Stohs \& Mauer (1996) argue that "firms trade off the benefits and costs of alternative debt maturity structures by taking into account the underinvestment cost of debt, the signaling effect of debt, liquidity risk, asset maturity structure, and tax status." They also find that debt maturity is inversely related to the firm quality.

\section{c. Review of Previous Empirical Researches:}

McConnel \& Servaes (1995) study the case of nonfinancial enterprises in the U.S. in the years 1976, 1986, and 1988. In each year of study, the samples are grouped into 'high-growth' firms and 'low-growth' firms. They found that high-growth firm's corporate value was negatively correlated with leverage (high Tobin's Q) and for the low-growth firm the correlation was positive (low Tobin's Q).

Franklin \& Muthusamy (2011) examine the impact of leverage on investment decisions using dataset from 1998 to 2009. They use pooling regression, random and fixed effect models to measure effects of leverage, sales, cash flow, return on asset, Tobin's Q, liquidity and retained earnings on investment and find a negative relationship between leverage investment for medium firms and positive relationship between leverage and investment in large firms.

Aivazian et al. (2005a) also study the impact of leverage on corporate investment decisions, which proves to be negative and significant as for low-growth firms rather than high-growth ones. The impact is substantial and sustainable in accordance with different ways of leverage measurement. 
In another study by Aivazian et al. (2005b), the impact of debt maturity on investment decisions is underpinned. Results of their study show that after controlling for the effect of the overall level of leverage, a higher percentage of long-term debt in total debt significantly reduces investment for firms with high growth opportunities. In contrast, the correlation between debt maturity and investment is not significant for firms with low growth opportunities.

Dang (2011) applies GMM and a panel of UK firms between 1996 and 2003 to investigate the effects of leverage and debt maturity on investment decisions. It is revealed that (1) high-growth firms control underinvestment incentives by reducing leverage but not by shortening debt maturity; (2) there is a positive correlation between leverage and debt maturity as predicted by liquidity risk hypothesis; and (3) leverage has a negative effect on firm investment levels, which is consistent with the overinvestment hypothesis regarding the disciplining role of leverage for firms with limited growth opportunities.

\section{METHODOLOGY}

\section{a. Data:}

The data are collected from HOSE and HNX, and from financial statements of 100 enterprises operating in real estate, rubber industry, pharmaceutical industry, health care, chemical industry, education, energy, mining industry, plastics, seafood, steel industry, trading sector, telecommunications, oil and gas, construction, etc. in the period 20072012 through several websites, such as www.cafef.vn, www.cophieu68.com, and www.vietstock.vn. These are arranged in a three-dimensional array, using three subscripts: year, enterprise and factor, which features an unbalanced panel dataset.

\section{b. Model:}

A system-based model is employed, based on the study by Dang (2011), including three structural equations: LEV, MAT and INV are considered as endogenous variables. 


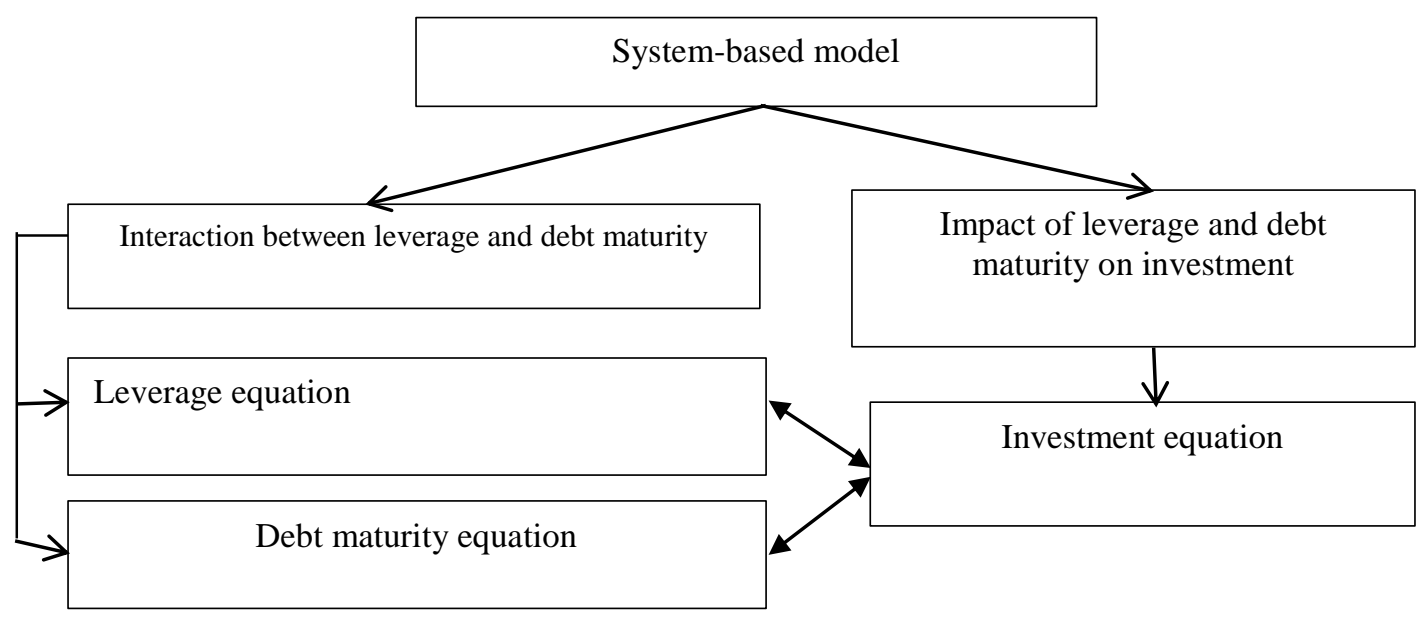

Source: Authors' design

\section{Figure 1: System-Based Model}

- Model of Interaction between Leverage and Debt Maturity:

The leverage equation is regarded as a partial adjustment model which lengthens debt maturity as well as its interaction with growth opportunities.

$L E V_{i, t}=\alpha_{0}+\delta_{L E V} L E V_{i, t-1}+\alpha_{1} M A T_{i, t}+\alpha_{2} G T H_{i, t}+\alpha_{3} G T H \times M A T_{i, t}+x_{i, t}^{L E V} \beta^{L E V}+\mu_{i}+u_{i, t}$

Where

$\mathrm{LEV}_{\mathrm{i}, \mathrm{t}}, \mathrm{MAT}_{\mathrm{i}, \mathrm{t}}, \mathrm{GTH}_{\mathrm{i}, \mathrm{t}}$ : leverage, debt maturity and growth opportunities at time $t$,

$x_{i, t}^{L E V}: 1 * \mathrm{k}$ vector, a determinant of leverage, which comprises four factors: tax shield (Tax_shield), tangibility (Tangibilit), profitability (Profitability) and corporate size (size), and

$\beta^{L E V}: \mathrm{k}^{*} 1$ coefficient vector.

Following the study by Dang (2011), the variables are measured as follows:

Leverage (LEV): total debt/total assets

Debt Maturity (MAT): Long-term debt maturing in one year/total assets

Growth Opportunities (GTH): (market value of share + book value of total liabilities)/total assets

Tangibility (Tangibilit): tangible fixed assets/total assets

Profitability (Profitability): EBITDA/total assets 
Tax shield (Tax_shield): Depreciation/total assets

Size: $\log$ of total assets

The estimated coefficients $\left(\alpha_{\mathrm{i}}\right)$ corresponding to the above variables suggest direct impact on leverage. According to the theory of underinvestment by Myers (1977), GTH is expected to have negative coefficients $\left(\alpha_{2}<0\right)$.

Growth opportunities are expected with the future profits and as with significant financial difficulties, firms with high-growth option may increase their investment (McConnel \& Servaes, 1995). This implies a positive relationship between the lag of growth opportunities and current investment expenditure.

- Model of Debt Maturity:

$M A T_{i, t}=\gamma_{0}+\delta_{M A T} M A T_{i, t-1}+\gamma_{1} L E V_{i, t}+\gamma_{2} G T H_{i, t}+\gamma_{3} G T H \times L E V_{i, t}+x_{i, t}^{M A T} \beta^{M A T}+\pi_{i}+v_{i, t}$

$x_{i, t}^{\text {MAT }}: 1 * 1$ vector of 5 determinants of debt maturity, including firm size (Size), asset maturity (Asset_mat), tax ratio (Tax_ratio), volatility (Volatility) and firm quality (Firm_quality) (Stohs \& Mauer, 1996).

$\beta^{M A T}: 1 * 1$ coefficient vector

Asset_mat: tangible fixed assets/depreciation

Tax_ratio: corporate income tax/profit before tax

Volatility: \% volatility of EBITDA - mean of volatility

Firm_quality: (EPS(t+1) - EPS(t))/market value(t)

- Model of Impact of Leverage and Debt Maturity on Investment:

To control the effects of financing decisions, including leverage and debt maturity, on investment, the following equation is introduced:

$$
\begin{aligned}
I N V_{i, t}=\varphi_{0}+ & \delta_{I N V} I N V_{i, t-1}+\varphi_{1} L E V_{i, t-1}+\varphi_{2} M A T_{i, t-1}+\varphi_{3} G T H_{i, t-1}+ \\
& \varphi_{4} G T H \times L E V_{i, t-1}+\varphi_{5} G T H \times M A T_{i, t-1}+\varphi_{6} C F_{i, t-1}+\emptyset_{i}+w_{i, t}
\end{aligned}
$$

$I N V_{i, t}$ : firm's investment

$C F_{i, t-1}$ : cash flow at $t-1$, calculated by (EBITDA + depreciation)/total assets (Jensen \& Meckling, 1976)

INV: (Capital expenditure - depreciation)/Value of fixed assets with lag 


\section{RESEARCH RESULTS}

\section{a. Analysis of Descriptive Statistics:}

Research data of the variables LEV, MAT, GTH and INV are as follows:

Table 1: Status of Endogenous Variables in the Period 2007-2012

\begin{tabular}{ccccc}
\hline & LEV & MAT & GTH & INV \\
\hline 2007 & 0.29318 & 0.18843 & 2.10411 & 1.46305 \\
2008 & 0.50180 & 0.17526 & 0.92848 & 0.58246 \\
2009 & 0.41104 & 0.17794 & 1.22793 & 0.40707 \\
2010 & 0.45046 & 0.15886 & 1.17566 & 0.33000 \\
2011 & 0.56130 & 0.14805 & 0.90607 & 0.30735 \\
2012 & 0.50692 & 0.16342 & 1.01023 & 0.37768 \\
\hline
\end{tabular}

Source: Authors' calculations

Financial leverage is employed by enterprises widely and increasingly in the period 2007-2012 with its peak in the years 2008 and 2011. Debt maturity has a tendency to be inversely proportional to leverage. MAT falls below 0.2 in 2007-2011 but then increases from 0.14 to 0.16 in 2012, which indicates that the debt structure of VN's enterprises mainly comprises short-term debts.

The mean of GTH is high in 2007 (>2) but decreases in 2008 - 2012. This is caused by the global financial crisis that led to a sharp fall in Vietnamese growth rate. INV reaches its peak in 2007 (around 1.46). From 2008, due to the impact of the crisis, investment falls drastically but then more slowly until 2011. Investment, however, reveals a modest increase in 2012 (from 0.3 to nearly 0.4 ); therefore, the difference in investment between 2007 and 2012 is crucial. 
Table 2: Descriptive Statistics of Variables (Sample 398)

\begin{tabular}{lccccccc}
\hline & Mean & Med. & Max. & Min. & Std. Dev & Skew. & Kurt. \\
\hline Lev & 0.455 & 0.436 & 0.955 & 0.016 & 0.256 & 0.105 & 1.830 \\
Mat & 0.169 & 0.080 & 0.926 & 0.000 & 0.213 & 1.637 & 4.994 \\
Gth & 1.227 & 0.977 & 12.688 & 0.220 & 0.939 & 5.663 & 53.422 \\
Inv & 0.499 & 0.117 & 16.417 & -1.823 & 1.329 & 5.361 & 47.981 \\
Tangibility & 0.270 & 0.238 & 0.939 & 0.006 & 0.178 & 1.091 & 4.288 \\
Tax_shield & 0.030 & 0.026 & 0.367 & 0.001 & 0.026 & 4.758 & 53.630 \\
Profitability & 0.141 & 0.117 & 0.670 & -0.160 & 0.110 & 1.638 & 7.117 \\
Size & 11.896 & 11.885 & 13.294 & 10.546 & 0.532 & 0.154 & 2.798 \\
Asset_mat & 11.562 & 9.081 & 94.451 & 0.376 & 10.320 & 3.555 & 20.700 \\
Volatility & 0.000 & -0.093 & 12.594 & -47.022 & 2.831 & -9.138 & 160.171 \\
Firm_quality & -0.042 & -0.013 & 0.837 & -1.812 & 0.222 & -1.933 & 15.503 \\
Tax_ratio & 0.151 & 0.140 & 2.773 & -0.822 & 0.170 & 6.294 & 101.083 \\
Cash_flow & 0.172 & 0.148 & 0.710 & -0.132 & 0.117 & 1.490 & 6.287 \\
\hline
\end{tabular}

Source: Authors' calculations

High mean (0.455) and med (0.436) of LEV suggest that enterprises are to encounter a high risk in investment, whereas low mean (0.169) and med (0.080) of MAT indicate that Vietnamese enterprises primarily raise capital through the banking channel, which is mainly short-term debt. Mean of INV (0.499) and its med (0.117) show a significant difference. In the crisis, investment is dramatically affected as the majority of shareholders and managers, being afraid of taking risks, do not want to make investment. The values of GTH denote stability, with not a high mean (1.227) and med (0.977), reflecting an expectation of economic recovery.

The remaining variables - tangibility, tax shield, profitability, size, asset maturity, income volatility, firm quality, tax ratio and cash flow - all follow normal distributions and without much value fluctuation that affects the sample. Mean of volatility is around 
0 due to the unbalanced panel data and post-crisis impacts. Firm quality has negative values of mean and med, for profit per share of this year tends to decrease compared to that of the previous one.

b. Analysis of Correlation between Variables:

Table 3: Correlation Matrix of Independent Variables in Leverage Equation

\begin{tabular}{|c|c|c|c|c|c|c|c|c|}
\hline & $\operatorname{Lev}(-1)$ & Mat & $\begin{array}{c}\text { Mat_ } \\
\text { gth }\end{array}$ & Gth & Tangibility & $\begin{array}{c}\text { Tax } \\
\text { shield }\end{array}$ & Profitability & Size \\
\hline \multirow[t]{2}{*}{$\operatorname{Lev}(-1)$} & 1.000 & & & & & & & \\
\hline & ----- & & & & & & & \\
\hline \multirow[t]{2}{*}{ Mat } & 0.104 & 1.000 & & & & & & \\
\hline & 0.021 & ----- & & & & & & \\
\hline \multirow[t]{2}{*}{ Mat_gth } & 0.045 & 0.917 & 1.000 & & & & & \\
\hline & 0.315 & 0.000 & ----- & & & & & \\
\hline \multirow[t]{2}{*}{ Gth } & -0.218 & -0.052 & 0.152 & 1.000 & & & & \\
\hline & 0.000 & 0.248 & 0.001 & ----- & & & & \\
\hline \multirow[t]{2}{*}{ Tangibility } & 0.032 & 0.614 & 0.580 & -0.050 & 1.000 & & & \\
\hline & 0.479 & 0.000 & 0.000 & 0.260 & ----- & & & \\
\hline \multirow[t]{2}{*}{ Tax_shield } & 0.024 & 0.298 & 0.367 & 0.052 & 0.413 & 1.000 & & \\
\hline & 0.589 & 0.000 & 0.000 & 0.248 & 0.000 & ----- & & \\
\hline \multirow[t]{2}{*}{ Profitability } & -0.401 & -0.125 & -0.005 & 0.496 & -0.077 & 0.130 & 1.000 & \\
\hline & 0.000 & 0.005 & 0.912 & 0.000 & 0.086 & 0.004 & ----- & \\
\hline \multirow[t]{2}{*}{ Size } & 0.272 & 0.332 & 0.261 & -0.055 & 0.219 & -0.022 & -0.209 & 1.000 \\
\hline & 0.000 & 0.000 & 0.000 & 0.223 & 0.000 & 0.624 & 0.000 & ----- \\
\hline
\end{tabular}

Source: Authors' calculations

Correlation coefficients of MAT and MAT_GTH are high (0.917). Since MAT_GTH is based on MAT, these two variables are not independent. In regression estimation, 
MAT and MAT_GTH, therefore, are eliminated in turn to avoid the impact of interactions between them on the model. Furthermore, high coefficients of the moderate positive correlation between TANGIBILITY and MAT and MAT_GTH $(0.614$ and 0.580 ), and other weak ones suggest that most of the variables are independent from one another.

Table 4: Correlation Matrix of Independent Variables in Debt Maturity Equation

\begin{tabular}{|c|c|c|c|c|c|c|c|c|c|}
\hline & $\begin{array}{l}\text { Mat } \\
(-1)\end{array}$ & Lev & Lev_gth & Gth & Size & $\begin{array}{c}\text { Asset_ } \\
\text { mat }\end{array}$ & $\begin{array}{l}\text { Tax_ } \\
\text { ratio }\end{array}$ & Volatility & $\begin{array}{l}\text { Firm_ } \\
\text { quality }\end{array}$ \\
\hline \multirow[t]{2}{*}{ Mat(-1) } & 1.000 & & & & & & & & \\
\hline & ----- & & & & & & & & \\
\hline \multirow[t]{2}{*}{ Lev } & 0.176 & 1.000 & & & & & & & \\
\hline & 0.000 & ----- & & & & & & & \\
\hline \multirow[t]{2}{*}{ Lev_gth } & 0.179 & 0.752 & 1.000 & & & & & & \\
\hline & 0.000 & 0.000 & ----- & & & & & & \\
\hline \multirow[t]{2}{*}{ Gth } & -0.028 & -0.369 & 0.120 & 1.000 & & & & & \\
\hline & 0.539 & 0.000 & 0.014 & ----- & & & & & \\
\hline \multirow[t]{2}{*}{ Size } & 0.326 & 0.289 & 0.274 & -0.054 & 1.000 & & & & \\
\hline & 0.000 & 0.000 & 0.000 & 0.231 & ----- & & & & \\
\hline \multirow[t]{2}{*}{ Asset_mat } & 0.115 & 0.064 & 0.019 & -0.086 & 0.153 & 1.000 & & & \\
\hline & 0.010 & 0.156 & 0.675 & 0.056 & 0.001 & ----- & & & \\
\hline \multirow[t]{2}{*}{ Tax_ratio } & 0.038 & 0.090 & 0.080 & -0.034 & 0.121 & 0.023 & 1.000 & & \\
\hline & 0.400 & 0.046 & 0.076 & 0.452 & 0.007 & 0.615 & ----- & & \\
\hline \multirow[t]{2}{*}{ Volatility } & -0.030 & -0.007 & -0.003 & 0.012 & 0.003 & 0.006 & 0.012 & 1.000 & \\
\hline & 0.507 & 0.879 & 0.939 & 0.787 & 0.954 & 0.899 & 0.784 & ----- & \\
\hline \multirow[t]{2}{*}{ Firm_quality } & -0.027 & -0.147 & -0.029 & 0.096 & -0.038 & -0.010 & 0.027 & 0.032 & 1.000 \\
\hline & 0.550 & 0.001 & 0.517 & 0.033 & 0.398 & 0.830 & 0.551 & 0.483 & ----- \\
\hline
\end{tabular}

Source: Authors' calculations based on Eviews 7.0 
In the debt maturity equation, correlation coefficients of LEV and LEV_GTH are high (0.752). Thus, in regression estimation, these are eliminated in turn to avoid the impact of interactions on the model. In addition, correlation values of others, such as SIZE, MAT(-1), LEV_GTH and LEV are below 0.4 and moderate negative correlations exist between GTH and LEV, and between GTH and MAT(-1).

Table 5: Correlation Matrix of Independent Variables in Investment Equation

\begin{tabular}{|c|c|c|c|c|c|c|}
\hline & $\operatorname{Lev}(-1)$ & Lev_gth(-1) & Mat(-1) & Mat_gth(-1) & Gth(-1) & $\begin{array}{c}\text { Cash_ } \\
\text { flow(-1) }\end{array}$ \\
\hline \multirow[t]{2}{*}{$\operatorname{Lev}(-1)$} & 1.000 & & & & & \\
\hline & ----- & & & & & \\
\hline \multirow[t]{2}{*}{ Lev_gth(-1) } & 0.670 & 1.000 & & & & \\
\hline & 0.000 & ----- & & & & \\
\hline \multirow[t]{2}{*}{ Mat(-1) } & 0.141 & 0.167 & 1.000 & & & \\
\hline & 0.002 & 0.000 & ----- & & & \\
\hline \multirow[t]{2}{*}{ Mat_gth(-1) } & -0.086 & 0.089 & 0.572 & 1.000 & & \\
\hline & 0.056 & 0.048 & 0.000 & ----- & & \\
\hline \multirow[t]{2}{*}{ Gth $(-1)$} & -0.400 & 0.056 & 0.066 & 0.581 & 1.000 & \\
\hline & 0.000 & 0.212 & 0.139 & 0.000 & ----- & \\
\hline \multirow[t]{2}{*}{ Cash_flow(-1) } & -0.428 & -0.253 & -0.052 & 0.047 & 0.307 & 1.000 \\
\hline & 0.000 & 0.000 & 0.248 & 0.293 & 0.000 & ----- \\
\hline
\end{tabular}

Source: Authors' calculations based on Eviews 7.0

In the investment equation, correlation coefficients of LEV_GTH (-1) and LEV (-1), MAT_GTH (-1) and MAT (-1), and MAT_GTH (-1) and GTH (-1) are high (0.670, 0.572 , and 0.581 respectively). Therefore, these pairs of variables (MAT \& MAT_GTH, and LEV \& LEV_GTH), are eliminated in turn. The variables also have moderate correlations, including negative one between CASH_FLOW (-1) and LEV (-1), LEV_GTH and positive one between GTH(-1) and MAT_GTH. 


\section{c. Results:}

- Regression Results of Leverage Equation:

Table 6 illustrates the following: Model (1) (as a primary model) - Impact of variables on leverage; Model (2) - Impact of variables on leverage, excluding interaction between debt maturity and growth; and Model (3) - Impact of variables on leverage, excluding growth.

OLS is employed in column (A), while GMM, in column (B). Most of the controlled variables are statistically significant. Regarding OLS, R-square is relatively high $(>0.8)$ besides low t-statistics; OLS, therefore, is considered inappropriate due to the possibility of multicollinearity. However, Durbin - Watson test indicates no autocorrelation between independent variables. Given GMM, J-test and AR(2) show that the use of instrument variables is appropriate; thus, GMM is basically applied in the research.

Table 6: Results of Regression in Leverage Equation (LEV)

Dependent variable: $\mathbf{L E V}$

\begin{tabular}{|c|c|c|c|c|c|c|}
\hline \multirow{2}{*}{$\begin{array}{c}\text { Independent } \\
\text { variable }\end{array}$} & \multicolumn{2}{|c|}{ (1) } & \multicolumn{2}{|c|}{ (2) } & \multicolumn{2}{|c|}{ (3) } \\
\hline & (A) & (B) & (A) & (B) & (A) & (B) \\
\hline $\operatorname{Lev}(-1)$ & $0.6614 * * *$ & $-0.1375 * * *$ & $0.6605 * * *$ & $-0.1374 * * *$ & $0.6697 * * *$ & $-0.1331 * * *$ \\
\hline Mat & $0.1788 *$ & $-1.0871 * * *$ & $0.0587 *$ & $-1.1547 * * *$ & $0.3192 * * *$ & $-1.0694 * * *$ \\
\hline Mat_gth & $-0.1126^{*}$ & $-1.2049 * * *$ & - & - & $-0.2498 * * *$ & $-1.2473 * * *$ \\
\hline Gth & $-0.0504 * * *$ & $-0.6702 *$ & $-0.0592 * * *$ & $-1.1270 * * *$ & - & - \\
\hline Tangibility & -0.0074 & $1.0441 * *$ & -0.0062 & $-0.5013^{*}$ & -0.0101 & $0.6836^{*}$ \\
\hline Tax_shield & 0.3086 & $-2.3129 * * *$ & 0.2356 & $0.9773 * *$ & $0.4005^{*}$ & $-1.9409 * * *$ \\
\hline Profitability & $-0.5048 * * *$ & 0.3165 & $-0.5124 * * *$ & $-2.1620 * * *$ & $-0.5950 * * *$ & -0.2210 \\
\hline Size & $0.0170 *$ & $0.8957 * * *$ & $0.0200 *$ & $0.8580 * * *$ & 0.0133 & $0.8189 * * *$ \\
\hline R-square & 0.806139 & - & 0.808799 & - & 0.796526 & - \\
\hline $\begin{array}{l}\text { Durbin- } \\
\text { Watson }\end{array}$ & 1.907929 & - & 1.932853 & - & 1.979115 & - \\
\hline
\end{tabular}


J-statistic Test

$\operatorname{AR}(2)$
$-2.1067$

0.878212
0.0000

$-2.1229$

0.858128

0.827906

$*, * *$, and $* * *$ denote significance at $10 \%, 5 \%$, and $1 \%$ respectively

Source: Authors' calculations based on Eviews 7.0

The testing coefficients of lagged leverage are significant at $1 \%$ in all three models, which is consistent with the pecking order theory by Mayers \& Majluf (1984), trade-off theory of capital structure and test results by Dang (2011). Correlation coefficients between lagged leverage and leverage, which are $0.1375,0.1374$ and 0.1331 , imply a fast change in leverage within enterprises.

Coefficients of debt maturity are significant at $1 \%$ in Model (1) and Model (3), similar to test results by Dang (2011). This is also consistent with a positive correlation between debt maturity and leverage as expected by Childs et al. (2005), which suggests that firms with short-term debt facing potential liquidity risk may be encouraged to apply leverage reduction. In contrast, firms with long-term debt facing the risk apply the policy less often.

The test results of interaction between growth opportunities and leverage are significant to Model (1) with the significance at $10 \%$ and negative coefficient of -0.6702 . Model (2) reveals significance at $1 \%$ and negative coefficient of -0.1270 , strongly supporting the argument of underinvestment by Myers (1977).

Maximum/minimum coefficients of interaction between MAT and LEV are 1.1547 and 1.0694, whereas those between MAT_GTH and LEV are -1.2473 and -1.2049. As with a mean of growth opportunities (-1.227), a negative interaction between leverage and growth opportunities is revealed. Profitability, as one of the controlled variables, is significant at $1 \%$.

- Results of Debt Maturity Equation:

Table 7 include results of the following: Model (1) (as a primary model) - Impact of variables on debt maturity; Model (2) - Impact of variables on debt maturity, excluding the interaction between leverage and growth; and Model (3) - Impact of variables on debt maturity, excluding growth. 
Table 7: Results of Regression in Debt Maturity Equation (MAT)

Dependent variable: MAT

\begin{tabular}{|c|c|c|c|c|c|c|}
\hline \multirow{2}{*}{$\begin{array}{c}\text { Independent } \\
\text { variable }\end{array}$} & \multicolumn{2}{|c|}{ (1) } & \multicolumn{2}{|c|}{ (2) } & \multicolumn{2}{|c|}{ (3) } \\
\hline & (A) & (B) & (A) & (B) & (A) & (B) \\
\hline Mat(-1) & $0.8701 * * *$ & $0.4516^{* * *}$ & $0.8707 * * *$ & $0.4538 * * *$ & $0.8701 * * *$ & $0.4052 * * *$ \\
\hline Lev & -0.0158 & $0.1530 *$ & 0.0025 & $0.1567 *$ & -0.0096 & $0.1151 *$ \\
\hline Lev_gth & 0.0201 & 0.0101 & - & - & 0.0153 & 0.0527 \\
\hline Gth & -0.0023 & $0.0574 *$ & 0.0016 & $0.0579 *$ & - & - \\
\hline Size & 0.0051 & 0.1043 & 0.0056 & 0.1072 & 0.0054 & 0.0654 \\
\hline Asset_mat & $0.0006 * *$ & $0.0027 * * *$ & $0.0006^{* *}$ & $0.0027 * * *$ & $0.0006 * *$ & $0.0026 * * *$ \\
\hline Tax_ratio & 0.0106 & 0.0609 & 0.0089 & 0.0677 & 0.0113 & 0.0440 \\
\hline Volatility & $0.0025 * *$ & -0.0070 & $0.0025^{* *}$ & -0.0070 & $0.0025 * *$ & -0.0020 \\
\hline Firm_quality & -0.0005 & -0.0130 & -0.0003 & -0.0143 & -0.0007 & -0.0284 \\
\hline R-square & 0.8734 & - & 0.8740 & - & 0.8748 & - \\
\hline $\begin{array}{l}\text { Durbin- } \\
\mathbf{x} / \mathbf{n t a n n}\end{array}$ & 2.026935 & - & 2.028656 & - & 2.023728 & - \\
\hline $\begin{array}{l}\text { J-statistic } \\
\text { Tant }\end{array}$ & - & 0.959419 & - & 0.955810 & - & 0.898333 \\
\hline $\mathrm{AR}(2)$ & - & 0.4442 & - & 0.4479 & - & 0.2271 \\
\hline
\end{tabular}

$*, * *$, and $* * *$ denote significance at $10 \%, 5 \%$, and $1 \%$ respectively

Source: Authors' calculations based on Eviews 7.0

The lagged variable of debt maturity is significant at $1 \%$ in all three models, which is compliant with the study on optimal debt maturity structure by Antoniou \& Paudyal (2006). The leverage is significant at $10 \%$ in all three models, corresponding to results of Model (1). It indicates that the positive relationship between leverage and debt maturity is sustainable, as applied to both regression models (1) and (2).

In Model (3), the variable growth opportunities is eliminated to avoid any correlation between interactions by growth opportunities and leverage. The results from Model (1) and Model (3) suggest that interaction between growth opportunities and leverage has 
no impact on debt maturity, compliant with the study by Dang (2011). Debt maturity, along with leverage, increases despite growth prospects, in connection with underinvestment. This result does not support the role of short-term debt maturity as an alternative for leverage reduction.

Model (1) and Model (2) reveal that correlation coefficients of debt maturity and growth opportunities are positive and are significant at $10 \%$, which suggests no economic relation between leverage and debt maturity, implying that enterprises may lower leverage instead of shortening debt maturity to control underinvestment. The results are partially consistent with implications by Myers (1977) that both leverage and debt maturity have negative correlation with growth opportunities and with findings by Stohs \& Mauer (1996) that there is no negative interaction between debt maturity and growth opportunities. Therefore, the research confirms that enterprises with high growth opportunities will reduce leverage instead of shortening debt maturity to limit underinvestment. In terms of controlled variables, asset maturity has significance at $1 \%$.

The results of the model which evaluates the impact of variables on LEV and MAT show that in Vietnamese market, there exists a positive correlation between leverage and debt maturity, mutually complementary in control of suboptimal liquidity.

- Results of Investment Equation:

The results in Table 8 include the following: Model (1) (as a primary model) - Impact of variables on investment; Model (2) - Impact of variables on investment, excluding leverage and investment; Model (3) - Impact of variables on investment, excluding debt maturity and interaction between debt maturity and growth opportunities; and Model (4) - Impact of variables on investment, excluding leverage and interaction between leverage and growth opportunities.

Table 8: Results of Regression in Investment Equation (INV)

\begin{tabular}{|c|c|c|c|c|c|c|c|c|}
\hline \multicolumn{9}{|c|}{ Dependent variable: INV } \\
\hline \multirow{2}{*}{$\begin{array}{c}\text { Independent } \\
\text { variable }\end{array}$} & \multicolumn{2}{|c|}{ (1) } & \multicolumn{2}{|c|}{ (2) } & \multicolumn{2}{|c|}{ (3) } & \multicolumn{2}{|c|}{ (4) } \\
\hline & (A) & (B) & (A) & (B) & (A) & (B) & (A) & (B) \\
\hline $\operatorname{inv}(-1)$ & 0.019 & $-0.129 * * *$ & 0.026 & $-0.097 *$ & 0.036 & $-0.199 * *$ & 0.016 & $-0.123 * * *$ \\
\hline $\operatorname{lev}(-1)$ & -0.083 & $-0.935 * *$ & - & - & -0.074 & $-2.215^{*}$ & - & - \\
\hline Lev_gth(-1) & 0.116 & $-1.320 * * *$ & 0.054 & -1.121 & 0.030 & 0.926 & - & - \\
\hline
\end{tabular}




\begin{tabular}{lcccccccc} 
Mat(-1) & $-0.488^{* * *}$ & 0.674 & - & - & - & - & $-0.485 * * *$ & -0.305 \\
Mat_gth(-1) & -0.043 & $-1.981^{* * *}$ & - & $-1.532^{* *}$ & - & - & -0.042 & $-1.508^{* * *}$ \\
Gth(-1) & 0.015 & $0.829 * * *$ & $0.110^{* *}$ & $0.681^{* *}$ & -0.011 & -0.153 & 0.041 & $0.605 * * *$ \\
cash_flow(-1) & 0.277 & $-1.903 * * *$ & $0.482^{*}$ & $-2.945 * *$ & $0.660^{* *}$ & -0.590 & 0.244 & $-1.206^{* * *}$ \\
R-square & 0.3857 & - & 0.1871 & - & 0.0448 & - & 0.3789 & - \\
$\begin{array}{l}\text { Durbin- } \\
\text { Watson }\end{array}$ & 1.6624 & - & 1.6746 & - & 1.5960 & - & 1.6567 & - \\
J-Test & - & 0.862872 & - & 0.943781 & - & 0.890517 & - & 0.721898 \\
AR(2) & - & 0.0613 & - & 0.0372 & - & 0.0838 & - & 0.0268 \\
\hline
\end{tabular}

$*, * *$, and $* * *$ denote significance at $10 \%, 5 \%$, and $1 \%$ respectively

Source: Authors' calculations based on Eviews 7.0

Table 8 illustrates results of Model (3) - Impact of leverage and debt maturity on investment. The variable lag of investment is statistically significant at $1 \%$ in Models (1) and (4), 5\% in Model (3), and 10\% in Model (2). This argues for the existence of an accelerated investment effect; investment in the current year is partly influenced by past investment.

Lag of leverage has negative impact on investment and is significant at 10\% in Model (1) and Model (3), which corresponds to empirical evidence by Aivazian et al. (2005) and Dang (2011), and supports predictions of agency theory by Jensen \& Meckling (1976). This test result may support the point of underinvestment: when underinvestment cannot be reduced because of a too high cost of leverage adjustment or failure to identify high growth opportunities early, maintaining a high leverage or reducing the planned leverage will affect investment results. Interaction coefficient of -0.935 indicates that an increase of $1 \%$ in leverage leads to a reduction of $0.935 \%$ in investment.

Coefficient of interaction between lagged leverage and growth opportunities on investment is negative and significant at $1 \%$ level [except in Model (2) and (3)]. As for general impact of growth opportunities on investment, results support the hypothesis that an adoption of low leverage helps control underinvestment and argues against the one that low leverage can maximize the positive relationship between growth opportunities and investment. According to Dang (2011), if leverage reduction strategy helps control the underinvestment, interaction coefficient will be negative. 
Lagged debt maturity in Models (1) and (4) shows no economic relations between debt maturity and firm investment, consistent with findings by Dang (2011) and Aivazian et al. (2005b). Moreover, coefficient of interaction between debt maturity and growth opportunities on investment is negative and significant at $1 \%$ and 5\% in Model (1) and Models (2), (4) respectively. This suggests that long-term debt maturity diminishes the positive relationship between lag of growth opportunities and current investment. Thus, if enterprises do not actively shorten debt maturity to minimize underinvestment-related problems, the maturity of long-term debt will hinder them from seizing golden growth opportunities.

Lagged growth opportunities has a positive impact on investment with significance at $1 \%$ [except in Model (3)], consistent with test results by Dang (2011). The results of lagged cash flow with negative interaction coefficient and significant levels of $1 \%$ [except in Model (3)] are different from empirical findings by Dang (2011). This shows that risk pressure born by investors forces managers to offer higher dividends.

\section{CONCLUSION}

\section{a. Results:}

The paper examines potential interaction between financing decisions and investment ones along the existence of agency problems. The results suggest that there are a positive correlation between leverage and debt maturity and a negative correlation between leverage and firm's investment (a reduction of leverage by $1 \%$ results in an increase of $0.935 \%$ in corresponding investment), and no interaction between debt maturity and investment. Furthermore, leverage and debt maturity can be employed as alternative strategies to control liquidity risk but not underinvestment. Vietnam's enterprises manage underinvestment by reducing leverage but not debt maturity and prefer to maintain low leverage because overuse of debt maturity would raise interest expense, which diminishes benefits from reduction in agency cost.

In practice, Vietnam's enterprises tend to apply a high leverage to take advantage of investment opportunities. Short-term debt is mainly employed in the period 2007-2012; therefore, reducing leverage may help enterprises avoid underinvestment-related problems.

\section{b. Recommendations on Firm's Financing Policies and Investment Decisions:}

Based on the research results, the following recommendations are made concerning financing policies on investment opportunities of Vietnam's enterprises: 
First, between 2007 and 2012, adoption of high leverage is to control interest rate risk and financial risk that affect firm's investment. Thus, there is a need for debt policies, consistent with investment decisions, and identification of growth opportunities and future cash flow to finance long-term debts and convertible bonds. More importantly, enterprises should consider the transfer of risks born by creditors to shareholders by making investment which is riskier than debts already financed.

Second, given the research results, high-growth firms do control underinvestment by reducing leverage but not debt maturity. These should base on investment strategies and status of financial/stock markets to restructure their capital and choose a rational capital structure thereby avoiding underinvestment-related problems.

Last, since there is no interaction between debt maturity and firm's investment, local enterprises should diversify funding sources when formulating their investment strategies and refrain from limiting debt maturity because it may lead to underinvestment. Corporate investment policies should count on the factors that may increase corporate profits, cash flow or net worth, ensuring interest harmony between creditors and shareholders

\section{References}

Aivazian, V.A., Y. Geb \& J. Qiu (2005a), “The Impact of Leverage on Firm Investment: Canadian Evidence", Journal of Corporate Finance, Vol.11(1), pp.277-291.

Aivazian, V.A., Y. Geb \& J. Qiu (2005b), “Debt Maturity Structure and Firm Investment”, Financial Management, Vol.34(4), pp.107-119.

Antoniou, A., Y. Guney \& K. Paudyal (2006), "The Determinants of Debt Maturity Structure: Evidence from France, Germany and the UK”, European Financial Management, Vol.12(2), pp.161-194.

Berk, J. \& P. DeMarzo (2007), Corporate Finance, Pearson.

Childs, P.D., D.C. Mauer \& S.H. Ott (2005), "Interactions of Corporate Financing and Investment Decisions: The Effect of Agency Conflicts”, Journal of Financial Economics, Vol.76(3), pp.667690.

Dang, V.A. (2011), "Leverage, Debt Maturity and Firm Investment: An Empirical Analysis", Journal of Business Finance and Accounting, Vol.38(1-2), pp.225-258.

Franklin, J. \& K. Muthusamy (2011), "Impact of Leverage on Firms Investment Decision", International Journal of Scientific \& Engineering Research, Vol.2(4), pp.1-16. 
Jensen, M. \& W. Meckling (1976), “Theory of the Firm: Managerial Behavior, Agency Costs and Ownership Structure”, Journal of Financial Economics, Vol.3(4), pp.305-360.

McConnell, J.J. \& H. Servaes (1995), "Equity Ownership and the Two Faces of Debt”, Journal of Financial Economics, Vol.39(1), pp.131-157.

Modigliani, F. \& M.H. Miller (1958), "The Cost of Capital, Corporation Finance and the Theory of Investment”, The American Economic Review, Vol.48(3), pp.261-297.

Myers, S.C. (1977), "Determinants of Corporate Borrowing", Journal of Financial Economics, Vol.5(2), pp.147-175.

Myers, S.C. \& N.S. Majluf (1984), “Corporate Financing and Investment Decisions When Firms Have Information that Investors Do Not Have”, Journal of Financial Economics, Vol.13(2), pp.187-221.

Stohs, M.H. \& D.C. Mauer (1996), "The Determinants of Corporate Debt Maturity Structure", Journal of Business, Vol.69(3), pp.279-312. 